Ali I Al-Niaimi

BDS, MDSc ( Lect)
Incidence Of Burkitt Lymphoma In The North Of Iraq

\section{Department of oral and maxillofacial surgery} College of Dentistry, University of Mosul

\title{
ABSTRACT
}

Aim : To describe the incidence of Burkitt lymphoma (BL) in the North Iraq with special regard to the incidence of BL of the jaw bone. Materials and Methods:The records of patients with lymphoma between the years 1981-1990 and 1995 -1999 in Hazim Al-Hafid Hospital in Mosul City were reviewed and they are analyzed with special regard to the BL including age,sex and the site distribution of the lesions. Results: One thousand and two records of the patients with lymphoma were reviewed .Seventy cases of them were BL consisting $7 \%$ of all lymphomas. Four cases $(5.7 \%)$ of the BL were present as jaw bone lesion. The age range for patients with BL of the jaw bone was 4-12 years with mean of age 7.5 years. All patients of BL of the jaw bones were male .No lesion of the jaw bone showed metastasis to the brain where prognosis become worse. Conclusions: $\mathrm{BL}$ in our country can be occurred in the intestine and even in the jaw bone so it must be included in our differential diagnosis of the jaw bone lesions.

Key words: Burkitt lymphoma , Lymphoma.

Al- Niaimi AI. Incidence Of Burkitt Lymphoma In The North Of Iraq. Al-Rafidain Dent J. 2010; 10(1): $84-88$.

Received: $22 / 10 / 2008$

Sent to Referees: $23 / 10 / 2008$

Accepted for Publication: 30/11/2008

\section{INTRODUCTION}

Burkitt lymphoma (BL) is a high grade B-cell neoplasm and is the most common malignancy in African children, but can occur sporadically in every country ${ }^{(1,2)}$. In equatorial Africa and other tropical locations, the incidence of BL is 100 per million children ${ }^{(3)}$ and account for $50 \%$ of all childhood malignancies ${ }^{(4)}$. While, in USA BL is very rare with about 100 new cases occurring in each year ${ }^{(3)}$ it constitutes of 6 $10 \%$ of childhood malignancies in USA (5)

BL first described in 1958 by a British surgeon called Dennis Burkitt

Who was working in Central Africa . He described an unusual type of lym- phoma ,which was very common in children, this became known as $\mathrm{BL}^{(6)}$.

As with other cancers the exact cause in not known, but later researches showed that B - Lymphocyte in those children had been infected with the Epstein - Barr virus (EBV) ${ }^{(5,6,7,8)}$. However, differences with regard to age and site of clinical presentation and rate of association to EBV are also observed in endemic and sporadic BL.Studies on BL has been showed that EBV is implicated strongly in the African form (about $100 \%$ ), while the relationship is less clear in the sporadic form (ranging between $10-30 \%)^{(4,9)}$.

The lymphocyte has receptors for EBV and one it's specific target .In 
the Africa form ,the hosts are believed to be unable to mount an appropriate immune response to primary EBV infection, possibly because of coexistent malaria infection that is immune suppressor and the host is unable to generate an adequate T- lymphocyte response (ie,EBV specific cytotoxic T- cell) against B-cells that are infected latently with EBV .This subsequently result in $\mathrm{B}$ - cell proliferation and ultimately result in chromosomal translocation involving $\mathrm{C}$-myc gene lead to malignan$\mathrm{cy}^{(10)}$.

Both sporadic and endemic form of $\mathrm{BL}$ are characterized by a translocation of the $\mathrm{C}$ - myc oncogene from chromosome 8 to either the immunoglobuline heavy chain region on chromosome 14 or one of the light chain loci on chromosome 2 (kappa light chain) or chromosome

22 ( lambda light chain) ${ }^{(3,4)}$.

This study is carried out to describe the incidence of BL in the North Iraq in regard to the clinical presentation and jaw bones involvement .

\section{MATERIALS AND METHODS}

The record of patients with lymphoma between the years 1981-1990 and 1995
- 1999 in Hazim AL-Hafid Hospital for oncology and nuclear medicine in Mosul City that consider officially as center for the North Iraq for oncology, all where reviewed with special concern to BL cases including the age and sex of the patients and the site of the tumor and the type of treatment received. The files of patients between the years 1991-1994 are not included because they were not available. The statistical analysis used in this study is descriptive .

\section{RESULTS}

The total cases of lymphoma between the years 1981-1990 were

400 only, 32 cases of them were BL and the total cases of lymphoma between the years 1995 - 1999 were 602 only 38 cases of them were BL. So the total number of lymphoma had been seen was 1002 cases only 70 cases of them were $\mathrm{BL}(7 \%)$. Most of the cases of BL were occurred in the abdomen and only 4 cases $(5.7 \%)$ of them occurred in the jaw bones.

Table (1) showed the site distribution of $\mathrm{BL}$ in which intestinal lesions appear to be the most common lesion while jaw lesions are rare.

Table (1): Distribution of the BL cases according to the site of involvement in the given period of time.

\begin{tabular}{ccccc}
\hline Year & $1981-1990$ & $1995-1999$ & No. & $\%$ \\
\hline Site & & & 60 & 85.7 \\
Intestine & 31 & 29 & 4 & 5.7 \\
Jaw Bones & 2 & 2 & 5 & 7.1 \\
Norvical Lymph & 4 & 1 & 1 & 1.4 \\
Jaw+Intestine & 1 & $/$ & 70 & 100 \\
Total & 38 & 32 & &
\end{tabular}

In general, the age range of the patients with BL was between 2 - 38 years with mean of age was 5.5 year. Separately ,for patients with BL in the intestine the age range was between $2-38$ years with mean of age 5.3 year while for patients with $\mathrm{BL}$ in the jaw bones the age range was between $4-12$ years with mean of age 7.5 year and for patients with BL in the cervical lymph nodes (CLN) the age rang was between $4-13$ years with mean of age 7 year and as shown in table (2) 
Table (2): Distribution of BL cases according to patients age.

\begin{tabular}{cccccc}
\hline $\begin{array}{c}\text { Site } \\
\text { Age }\end{array}$ & Jaw bone & CLN & Intestine & $\begin{array}{c}\text { Intestine+ } \\
\text { Jaw bone }\end{array}$ & Total \\
\hline $1-10$ & 3 & 4 & 57 & 1 & 65 \\
$11-20$ & 1 & 1 & 1 & $/$ & 3 \\
$21-30$ & $/$ & $/$ & 1 & $/$ & 1 \\
$31-40$ & $/$ & $/$ & 1 & $/$ & 1 \\
Total & 4 & 5 & 60 & 1 & 70 \\
\hline
\end{tabular}

In table (3) the male/female ratio in general was $2.6 / 1$. The male to female ratio in the jaw bone lesions and intestinal lesions were high in male than in female while in the cervical lymph node lesions there were slightly high incidence in female than in male.

Table (3):Distribution of BL cases according to patients sex.

\begin{tabular}{|c|c|c|c|c|}
\hline \multirow[t]{2}{*}{ Sex Site } & \multirow[t]{2}{*}{ Male } & \multirow[t]{2}{*}{ Female } & \multicolumn{2}{|c|}{ Total } \\
\hline & & & No. & $\%$ \\
\hline Jaw bone & 4 & I & 4 & 5.7 \\
\hline CLN & 2 & 3 & 5 & 7 \\
\hline Intestine & 44 & 16 & 60 & 85.7 \\
\hline $\begin{array}{l}\text { Intestine+ } \\
\text { Jaw bone }\end{array}$ & 1 & I & 1 & 1.4 \\
\hline Total & 51 & 19 & 70 & 100 \\
\hline
\end{tabular}

In table (4) we can seen that the age

to the second decade of life. rang for male is slightly wider extended

Table (4):The relation between patients age groups and sex.

\begin{tabular}{cccc}
\hline $\begin{array}{c}\text { Sex } \\
\text { Age }\end{array}$ & Male & Female & Total \\
\hline $1-10$ & 47 & 18 & 56 \\
$11-20$ & 3 & $/$ & 3 \\
$21-30$ & $/$ & 1 & 1 \\
$31-40$ & 1 & $/$ & 1 \\
$41-50$ & $/$ & $/$ & $/$ \\
$51-60$ & $/$ & $/$ & $/$ \\
$61-70$ & $/$ & $/$ & $/$ \\
Total & 51 & 19 & 70 \\
\hline
\end{tabular}


Table (5) showed that 5 cases of intestinal lesions were metastasized to the brain with no jaw lesion had secondary metastasis makes the prognosis of intestinal lesions more worse.

Table (5):The site distribution of the secondary tumor of BL

\begin{tabular}{ccccccc}
\hline $\begin{array}{c}\text { Primary } \\
\text { site }\end{array}$ & Intestine & Jaw & Brain & CLN & Liver\&Spleen & Others \\
\hline Jaw bone & $/$ & $/$ & $/$ & 1 & 1 & 1 \\
Intestine & $/$ & 2 & 5 & $/$ & 4 & 2 \\
CLN & 1 & $/$ & $/$ & $/$ & $/$ & $/$ \\
Combined & $/$ & $/$ & $/$ & $/$ & $/$ & $/$ \\
\hline
\end{tabular}

\section{DISCUSSION}

Although the histological appearance of endemic and sporadic BL are similar but their clinical presentations are different. The African form most often involve maxilla or mandible where as, involvement of abdominal organs and lymph nodes are less common. In contrast the sporadic form usually involves abdominal organs and lymph nodes and less commonly involve the facial bones $(1,11,12)$.

In this study BL representing about $7 \%$ of all lymphomas and jaw involvement was seen in 4 cases $(5.7 \%$ ),two cases in the maxilla and the other two cases in the mandible (one was involved the two sides of the mandible ), and this agrees with experience from USA ${ }^{(13)}$, Europe (14) and Malaysia (15) and disagrees with the endemic BL where jaw bone involvement account about $50-70 \%$ of $\mathrm{BL}$ in the body ${ }^{(15)}$.Also, lymph node involvement in our study was seen in 5 cases $(7.1 \%)$ which is in contrast with the rate in endemic areas which is less than $1 \%{ }^{(15)}$

Intestinal tumors formed the largest group in our study reaching up to 60 cases $(85.7 \%)$ which is in consistent with the clinical pattern of BL in sporadic form ${ }^{(4,5)}$

The vast majority of the patient's age in our study were between 2-13 years with median of age 7.5 years as in a study carried out in USA the median of age was 8 years $(0-21 \text { year })^{(16)}$ while some Asian countries such as Malaysia the median of age was 15.8 years $^{(15)}$. In Africa the mean of age 7 years ${ }^{(3)}$.
BL showed general predilection to occur in male with mild variation in male /female ratio .In this study the male /female ratio was 2.6/1 which agree with the endemic ratio of male / female of 2-3 $/ 1^{(3)}$ while in USA $4 / 1^{(16)}$ and in Malaysia $3.9 / 1^{(15)}$.

$\mathrm{BL}$ is a very fast growing tumor . Systemic chemotherapy is the treatment of choice of this aggressive disease in all it's stages. The overall survival rate of BL depends upon the stage of the disease at initial diagnosis . Patients with localized disease respond well to chemotherapy and have excellent survival rate .Patient with disseminated disease (patient with bone marrow and central nervous system involvement ) respond less well to chemotherapy and has a less favorable survival rate ${ }^{(17,18)}$.

In this study 5 cases ( $7 \%$ ) out off 70 cases of BL showed dissemination of the disease from the intestine to involve the central nervous system .The treatment regime were included the use of combination of chemotherapy and some cases needed the use of radiotherapy in addition to the chemotherapy and small operable BL

Lesion were subjected to surgery that followed by chemotherapy and / or radiotherapy but because of absence of full information about the follow-up of treatment of most if not all cases ,therefore collection of sufficient

Data about the outcome of the treatment of the cases were difficult. 
Three cases of BL of the intestine that needed chemotherapy did not received the required treatment because of the unavailability of the medicine in our country between the years 1995-1999 because our country was submitted to economic sanctions between the years 1990-2003.

\section{CONCLUSION}

BL is a highly malignant neoplasm and may occur in the jaw bones mainly of the children and it's early diagnosis and treatment may give the patient more chance to survive .

\section{REFERENCES}

1. Manolopoulos L, Nikolopoulos TP, Yiotakis J, Karapatsas J, Maris A and Ferekidis E: Burkitt's lymphoma in the base of the tongue: Differential diagnosis and management : ORL. 2003;65.226-229.

2. Leonard MP, Schlegel PN, Crovatto A ,Gearhard JP : Burkitt's lymphoma ,the testis: an nusual scrotal mass in childhood: J Urol. 1990 Jan;143(1): 104-6.

3. Link MP ,Shuster JJ and Donaldson SS: Treatment of children and young adult with early stage Non-Hodgkin's lymphoma:N Engl J Med. 1997; 337 (18): 125966.

4. 4.Regezi JA: Oral pathology in children and younge adult:Oral and Maxillofacial Surg Clinic of North America. 1994;6(1):21-26.

5. 5.Regezi JA,Sciubba JJ, ordan RCK. Oral pathology: Clinical pathologic correlation. 4th ed. Saunders AnImprint of Elsevier science. $2003 ; 331-333$.

6. Neville BW, Damm DD, Allen CM, Bouquot JE. Oral and maxillofacial pathology : $2^{\text {nd }}$ ed. Saunder AnImprint of Elsevier science $2002 ; 523-524$.

7. Chang DK ,Yoo DH ,Kim TH ,Kim IS, Jun KY, Park MH, Kim SY. Burkitt's lymphoma presentin as ileocaecal intussusception in systemic lupus erythematosus. Clinical Rheu.1999;18(3):253-6.

8. Fujitas S,Buziba N, Kumatori A,Semba M,Yamaguchi A and Toriyama K: Early stage of Epestien -Bar virus lytic infection leading to the (Starry sky) pattern formation in endemic Burkitt's lymphoma: Ach Pathol.Lab. Med. 2004 ; 128(5):549-52.

9. .Magrath I., The pathogenesis of Burkitt's lymphoma. .Adv.Cancer Res. 1990; 55. 133-270.

10. Bhatia KG,Guteirrez MI, Huppik, Siwar ski D, Magrath IT. The pattern of p53 mutation in BL differes from that of solid tumors. Cancer Res.1992; 52. 4273-4276.

11. Rao CR, Gutierrez MI, Bhatia K, Fend F, Franklin J, Appaji L, Gallo G,O'Conar G, Ialitha N, Magrath I. Association of BL with the EBV in two developing countries : Leuk Lymphoma.2000 ;39 (3-4):329-37.

12. Raja K. Jaw lymphoma in middle east children. British J Oral Surg. 1977; 15. 153-159.

13. Ziegler JL: Burkitt's lymphoma: New Engl.J.med.1981;305.735-744.

14. Philip T, Lenoir GM, Broyn PA, Gerard Marchant R, Sauillet G, Philippe N, Freycon F, Brunat-Mentigny M. Burkitt-type lymphoma in France amonge non-Hodgkin malignant lymphoma in Caucasian children. Br J cancer 1982 ;45 .670-678.

15. Suat-Cheng Peh, Yan-Chin Tai ,Lian-Hua Kim, Shaminie Jairaman, Shiaw-Sze Ganad Hai-Peng Lin. The pattern of Burkitt's lymphoma in Malaysian patients: $J$ Clin Exp Hematopathol . 2002;42(2):67-74.

16. Cairo MS, Sposto R, Perkin SL, Meadows AT, Hoover-Regan ML, Anderson JR, Siegel SE, Ione MA, Tedeschi-Blok N, Kadin ME, Kjeldsberg CR, Wilson JF, Sanger W, Marris E, Krailo MD, Finlay JL. Burkkit's and Burkitt -like lymphoma in children and adolescent:a review of the children's cancer group experience. British J Hematol . 2003; 120 (4):660.

17. Gasparini M, Rottoli L, Massimino M, Gianni MC, Ballerini E, Ravagnani F, Pupa S, Fossati-Bellanif. Curability of advanced Burkitt's lymphoma in children by intensive short -term chemotherapy: Eur $J$ cancer .1993;29A(5):692-8.

18. Mazza JJ, Hines JD, Anderson JW, Neiman RS, Mann R, Oken MM O'Connell MJ. Aggressive chemotherapy in the treatment of Burkitt's and non-Burkitt's undifferentiated lymphoma. Leuk Lymphoma 1995Jul; 18(3-4):289-96. 